\title{
O DIREITO À RAZOÁVEL DURAÇÃO DO PROCESSO: JUSTICIALIZAÇÃO INTERNACIONAL E NECESSIDADE DE APRIMORAMENTO DE SUA PROTEÇÃO NO ÂMBITO NACIONAL
}

\author{
Micheli Pereira ${ }^{1}$ \\ Cláudia Maria Barbosa ${ }^{1}$
}

\section{RESUMO}

Analisa-se neste artigo a responsabilização do Brasil à luz da Convenção Interamericana de Direitos Humanos, a qual foi ratificada por nosso país, demonstrando os seus mecanismos, dificuldades, bem como o auxílio que este sistema internacional vem conferindo aos Estados adeptos na proteção dos direitos humanos. Avalia-se como este meio internacional pode exercer força na concretização do direito à razoável duração do processo, unindo-se ao direito interno para conferir maior eficácia à proteção do cidadão e pressionando o Estado a tomar atitudes concretas na implementação de medidas que garantam maior agilidade na entrega da prestação jurisdicional.

Palavras-chave: Justicialização internacional. Proteção no âmbito Nacional. Razoável duração do processo.

\section{INTRODUÇÃO}

A justiça vem se tornando ineficaz por inúmeros motivos, dentre estes e talvez o maior deles, a sua excessiva morosidade. Aqueles que recorrem ao Judiciário para tutelar os seus direitos esbarram no problema da morosidade da Justiça e em um órgão que sofre de uma crise aguda, justamente no momento de sua maior procura. Tal poder não tem o dinamismo para fazer frente aos fenômenos da vida moderna, a qual demanda maior ativismo estatal. Por conta disso, não raras vezes, os jurisdicionados sofrem amargos prejuízos por conta da demora na prestação jurisdicional.

A morosidade da justiça é um fator que desencadeia problemas individuais, sociais, políticos e econômicos, e, no Brasil, apesar de ter sido editada a Emenda Constitucional ำ 45, com a instituição do novo princípio fundamental à razoável duração do processo, incluído no art. 5ㅇ, inciso LXXVIII, da Constituição Federal, esta garantia vem se tornando 'letra morta', e, ao que se evidencia, está se consolidando como um 'instrumento ideológico de controle das expectativas sociais $^{2}$, uma vez que falta interesse dos setores públicos em tornar a norma efetiva.

Toma-se como premissa deste trabalho que o direito à entrega da prestação jurisdicional em tempo razoável não se confunde com a indenização decorrente do descumprimento pelo Estado do referido preceito, uma vez que "o ideal é que não haja violação ao direito ou que esta seja excepcional”, ${ }^{3}$, eis que o instituto busca 
conferir ao cidadão a garantia a uma tutela em tempo razoável, a fim de que este não sofra danos de qualquer natureza. Contudo, em havendo a lesão a esse direito fundamental, entende-se que a indenização é devida, por duas razões: a) para ressarcir os jurisdicionados pelos prejuízos advindos da demora excessiva, b) para pressionar os poderes públicos a atuar mais detidamente da resolução do problema. ${ }^{4}$

Este trabalho trata da forma como a doutrina e a jurisprudência nacional vêm entendendo a questão da responsabilização do Estado pela violação ao direito à razoável duração do processo e como os meios de defesa nacionais estão sendo insuficientes para assegurar a observância do preceito fundamental. Sugere-se que, quiçá, a única forma de evitar a perpetuação de abusos ou a impunidade do Estado é com o auxilio dos órgãos jurisdicionais de proteção aos direitos humanos, eis que, para Mazzuoli, "o respeito aos direitos humanos não é assunto exclusivamente interno de um Estado, mas sim de toda a comunidade mundial" .

Faz-se uma análise de como a Constituição Federal de 1988 representa um marco na democratização do país e como ela está marcada pelo valor da dignidade da pessoa humana, o que se vê representado em vários de seus dispositivos. A proteção a esses direitos sobrepõe-se a princípios tradicionais como 0 da soberania, ${ }^{6}$ caracterizando o chamado constitucionalismo contemporâneo, que se abre ao direito internacional, impedindo que se fale em primazia das normas de direito interno, eis que o primado é sempre da norma que melhor protege os direitos humanos. ${ }^{7}$

Avalia-se o processo de abertura da Constituição Federal aos direitos humanos, os quais são por ela reconhecidos como norma constitucional, consoante interpretação dos artigos $4^{\circ}$, II e $5^{\circ}$, $\S 2^{\circ}$. Assim, o Brasil passa a assumir no plano internacional a obrigação de respeitar esses direitos, readequando seu ordenamento jurídico às garantias previstas nos pactos ratificados.

Trata-se da forma como os Estados Europeus são responsabilizados no âmbito internacional pela Corte Européia de Direitos Humanos, bem como do reflexo que essa responsabilização tem no âmbito interno dos Estados-partes. Dá-se especial destaque à Itália, a qual se obrigou a editar uma lei prevendo indenização aos cidadãos em razão da demora do processo, por conta da pressão política e das inúmeras condenações que sofreu junto à Corte Européia.

Examina-se, por fim, a responsabilização do Brasil à luz da Convenção Interamericana de Direitos Humanos, a qual foi ratificada por nosso país, demonstrando os seus mecanismos, dificuldades, bem como o auxílio que este sistema internacional vem conferindo aos Estados adeptos na proteção dos direitos humanos. Avalia-se como este meio internacional pode exercer força na concretização do direito à razoável duração do processo, unindo-se ao direito interno para conferir maior eficácia à proteção do cidadão e pressionando o Estado a tomar atitudes concretas na implementação de medidas que garantam maior agilidade na entrega da prestação jurisdicional. 


\section{RESPONSABILIDADE DO ESTADO BRASILEIRO PELA OFENSA AO DIREITO À RAZOÁVEL DURAÇÃO DO PROCESSO}

No plano nacional foi recentemente editada a Emenda Constitucional № 45, a qual veio a instituir, no art. 5을 inciso LXXVIII, da Constituição Federal, o princípio da razoável duração do processo, o qual prevê expressamente que: "a todos, no âmbito judicial e administrativo, são assegurados a razoável duração do processo e os meios que garantam a celeridade de sua tramitação".

Tendo a garantia da razoável duração do processo sido incorporada à Constituição como direito fundamental ao cidadão, e, portanto, com aplicabilidade imediata, consoante dispõe $\S 1^{\circ}$, do art. 5을 da Carta, caberia ao Poder Público atuar diretamente para conferir eficácia máxima a esse preceito, ou seja, caberia "aos poderes constituídos, em seu âmbito próprio de competência, a tarefa de realizar a função prospectiva, dinamizadora e transformadora desse princípio" ${ }^{\text {. Contudo, a }}$ atuação estatal ainda se mostra frágil e ineficiente, quiçá pela complexidade das causas que levam à morosidade da justiça.

No que toca à responsabilização do Estado pela violação do direito à razoável duração do processo, no plano doutrinário, o entendimento majoritário é o de sua responsabilização objetiva, o que se sustenta com fulcro no art. $37, \S 6^{\circ}$, da Constituição Federal. Isto porque a entrega da prestação jurisdicional pelo Estado constitui um serviço público, o qual deve ser exercido com eficiência e boaqualidade, correspondendo ao princípio da eficiência.

Juracy C. Silva, por exemplo, entende que:

[...] a atividade jurisdicional configura típico serviço público. Em dado momento de sua evolução, o Poder Público, ainda sob as vestes de formas proto-estatais, vedou aos particulares exercer justiça de mão própria, reservando para si a tarefa de reparar os direitos ameaçados ou violados. Data daí a instituição de um serviço público judiciário, ou, se preferir, da atividade jurisdicional como serviço público, porque serviço posto à disposição do público. $O$ tratar-se de serviço que não pode ser recusado pelos usuários, longe de desnaturar-lhe a essência, mais a corrobora. ${ }^{9}$

Portanto, a demora na entrega da prestação jurisdicional caracteriza serviço público imperfeito, seja em razão da indolência do juiz ou dos funcionários que atuam no processo, seja em razão do mau funcionamento da Justiça ${ }^{10}$. Paulo Hoffman também entende que a responsabilização do Estado pela exagerada duração do processo é objetiva, consoante expõe no trecho abaixo:

Nosso posicionamento é cristalino no sentido de que o Estado é responsável objetivamente pela exagerada duração do processo, motivada por culpa ou dolo do juiz, bem como por ineficiência da estrutura do Poder Judiciário, devendo indenizar o jurisdicionado prejudicado, autor, réu, independentemente de sair-se vencedor ou não na demanda, pelos prejuízos materiais e morais. ${ }^{11}$ 
Infere-se que a doutrina majoritária defende a responsabilidade objetiva do Estado, com base no art. 37, § 6º, da Constituição, em decorrência da adoção da teoria do risco administrativo, a qual determina que, "quando uma pessoa sofre ônus maior do que o suportado pelas demais, rompe-se o equilíbrio que deve haver entre os encargos sociais, devendo o Estado indenizar o prejudicado, para restabelecer o equilíbrio"12. Com a responsabilidade objetiva, a idéia de culpa é suprimida, cabendo ao prejudicado demonstrar apenas o nexo causal e o dano sofrido.

Celso Antônio Bandeira de Melo ${ }^{13}$ e Augusto do Amaral Dergint ${ }^{14}$, por sua vez, entendem que nos casos em que os danos provocados sejam oriundos de ato omissivo do Estado, ou seja, nos casos em que este era obrigado a evitá-los e não o fez, deve-se aplicar a responsabilidade subjetiva, uma vez que a conduta omissiva não seria a 'causadora do dano'. A causa do dano seria decorrente de atos de terceiro e/ou fato alheio. Assim, a responsabilidade do Estado seria subjetiva, uma vez que decorreria de comportamento ilícito, não existindo comportamento ilícito que não proveniente de negligência, imprudência e imperícia (culpa), ou ainda, decorrente da violação de norma que impunha certa obrigação (dolo). ${ }^{15}$

\section{Contrariamente, Frederico Augusto Leopoldino Koehler, assim se pronuncia:}

[...] a omissão do Estado é a causa direta e suficiente do dano, prescindindo de um fato da natureza ou de ato material praticado por terceiro. A atividade jurisdicional defeituosa do Estado configura, per se, a causa do dano. Por esse motivo, a responsabilidade estatal nessa situação é objetiva. ${ }^{16}$

A discussão feita pela doutrina quanto à responsabilidade aplicável ao Estado pela demora do processo, ou seja, se objetiva ou subjetiva, tem grande relevância no campo probatório, posto que a partir disso é possível definir a dispensa ou não de comprovação da culpa. Contudo, a fim de demonstrar o tamanho da divergência de entendimentos sobre o assunto, existem autores que sustentam que o Estado é responsável apenas por danos decorrentes da prestação jurisdicional nas hipóteses previstas em lei. ${ }^{17}$ Entretanto, refuta-se este argumento com a alegação de que o art. $37, \S 6^{\circ}$, da Constituição Federal é um princípio geral de responsabilidade, não havendo lei que determine que o juiz deva fundar seu julgamento somente na lei escrita. $^{18}$

Não menos polêmica é a relação da doutrina com a jurisprudência sobre o assunto. Embora a maior parte dos doutrinadores sustente que o Estado responde objetivamente pelos danos decorrentes da prestação jurisdicional intempestiva, a jurisprudência, inclusive consolidada por julgados do Supremo Tribunal Federal, apenas admite a responsabilização do Estado quando expressamente prevista em lei. ${ }^{19}$ Deste modo, prevalece a máxima de que 'não havendo lei específica, permanece a irresponsabilidade do Estado'.

Destarte, constata-se que a doutrina e a jurisprudência nacionais são insatisfatórias e conflitantes no que toca ao tema. Igualmente, não existem no plano interno formas de reivindicar, ou mesmo de se ver reparado de um dano oriundo da demora irracional de uma demanda, o que torna o princípio da razoável duração do processo 'simbólico'. Por essa razão, é preciso buscar, no plano internacional, 
respostas efetivas à proteção ao referido direito humano fundamental, eis que, consoante entendimento de Flávia Piovesan, os direitos fundamentais são acionáveis e demandam séria e responsável observância, especialmente por sua aplicabilidade imediata, o que faz com que os poderes políticos devam assumir a função de torná-los efetivos. ${ }^{20}$

\section{CONSTITUIÇÃO FEDERAL DE 1988: MARCO DE DEMOCRATIZAÇÃO, DA DIGNIDADE HUMANA E DA ABERTURA AOS DIREITOS HUMANOS}

Flávia Piovesan ensina que a Constituição Federal de 1988 possui duplo valor simbólico, qual seja: é marco jurídico de transição democrática e de instituição dos direitos humanos ${ }^{21}$. Ela representa uma ruptura com o regime autoritário instaurado em 1964, que perdurou até 1985. A Carta de 1988 também veio redefinir o regime de governo, e, principalmente, trazer aos cidadãos direitos e garantias fundamentais, dentre os quais, direitos sociais, políticos, coletivos, difusos, etc. Nessa perspectiva, a Carta Constitucional de 1988 colocou-se entre as Constituições mais avançadas do mundo no que diz respeito à matéria. ${ }^{22}$

Analisados os seus dispositivos, com especial atenção aos fundamentos da República, verifica-se que a Carta tem como fundamento central a dignidade da pessoa humana (art. $1^{\circ}$, inciso III), e este valor se reflete por todo ordenamento constitucional, no plano individual, social, político, e, inclusive, econômico, eis que, para Justen Filho, "as faculdades de desenvolver atividades econômicas e de buscar o lucro são instrumentos de realização da dignidade de todas as pessoas humanas envolvidas, sejam os empresários, sejam os demais integrantes da comunidade"23.

Ao referendar a dignidade da pessoa humana como valor central da República, a Carta afirma consequentemente o alcance universal dos direitos humanos, os quais decorrem da dignidade inerente a toda e qualquer pessoa, sem qualquer discriminação ${ }^{24}$. Além de referendar esse alcance universal, "o texto constitucional ainda reforça essa concepção, na medida em que realça que os direitos humanos são tema de legítimo interesse da comunidade internacional, transcendendo, por sua universalidade, as fronteiras do Estado" ${ }^{25}$, consoante se infere do texto do art. 4을 inciso II: "Art. 4․ A República Federativa do Brasil rege-se nas suas relações internacionais pelos seguintes princípios: II - prevalência dos direitos humanos".

O artigo em questão faz referência ao princípio da prevalência dos direitos humanos, o qual tem por escopo abrir a ordem jurídica interna ao sistema internacional de direitos humanos. Contudo, para Flávia Piovesan, esse princípio não implica apenas no engajamento do país na elaboração de normas vinculadas ao Direito Internacional dos Direitos Humanos, mas sim na plena integração entre essas regras e aquelas já existentes na ordem jurídica interna, veja-se:

Ao romper com a sistemática das Cartas anteriores, a Constituição de 1988, ineditamente, consagra o primado do respeito aos direitos humanos, como paradigma propugnado para a ordem internacional. Esse princípio invoca a abertura da ordem jurídica interna ao sistema internacional de proteção dos direitos humanos. A prevalência dos direitos humanos, como princípio a reger o Brasil no âmbito internacional, não implica apenas o engajamento 
do País no processo de elaboração de normas vinculadas ao Direto Internacional dos Direitos Humanos, mas sim a busca da plena integração de tais regras na ordem jurídica interna brasileira. Implica, ademais, o compromisso de adotar uma posição política contrária aos Estados em que os direitos humanos sejam gravemente desrespeitados. ${ }^{26}$

Contudo, a adoção do princípio da prevalência dois direitos humanos importa na flexibilização da noção de soberania, uma vez que exige que o país se abra às regras jurídicas internacionais que visam a proteção dos direitos humanos. Valério Muzzuoli assevera que, "à medida que os Estados assumem compromissos mútuos em convenções internacionais, que diminuem a competência discricionária de cada contratante, eles restringem sua soberania e isto constitui uma tendência do constitucionalismo contemporâneo"27. Aduz o referido autor que "não existem direitos humanos globais, internacionais e universais, sem uma soberania flexibilizada, o que impediria a projeção desses direitos na agenda internacional” ${ }^{28}$.

Assim, ao adotar o princípio da prevalência dos direitos humanos para reger o Brasil nas suas relações internacionais "está-se admitindo a concepção de que os direitos humanos constituem tema de legítima preocupação e interesse na comunidade internacional. Os direitos humanos, nessa concepção, surgem para a Carta de 1988 como tema global"29. Outrossim, de acordo com Celso Lafer, esse princípio auxilia que regramentos internacionais de direitos humanos sejam mais facilmente ratificados pelo Brasil, a exemplo da Convenção Americana de Direitos Humanos:

O princípio da prevalência dos direitos humanos foi um argumento constitucional politicamente importante para obter no Congresso a tramitação da Convenção Americana dos Direitos Humanos - o Pacto de San José. Foi em função dessa tramitação que logrei depositar na sede da OEA, nos últimos dias de minha gestão (25-09-92), o instrumento correspondente de adesão do Brasil a este significativo Pacto. ${ }^{30}$

Nesse mesmo contexto de inserção do país no cenário internacional, destacase outro dispositivo inédito na história brasileira, qual seja: $\S 2^{\circ}$, do art. 5ำ da Carta de 1988:

Art. $5^{\circ}$. [...] $\S 2^{\circ}$. Os direitos e garantias expressos nesta Constituição não excluem outros decorrentes do regime e dos princípios por ela adotados, ou dos tratados internacionais em que a República Federativa do Brasil seja parte.

Para Flávia Piovesan, a análise desse artigo possibilita concluir que a Constituição Federal de 1988 incluiu no catálogo de direitos constitucionalmente garantidos os direitos enunciados nos tratados internacionais em que o Brasil é parte, veja-se:

[...] ao prescrever que 'os direitos e garantias expressos na Constituição não excluem outros direitos decorrentes dos tratados internacionais', a contrario sensu, a Carta de 1988 está a incluir, no catálogo de direitos 
constitucionalmente protegidos, os direitos enunciados nos tratados internacionais em que o Brasil seja parte. Esse processo de inclusão implica a incorporação pelo Texto Constitucional de tais direitos.

Ao efetuar a incorporação, a Carta atribui aos direitos internacionais uma natureza especial e diferenciada, qual seja, a natureza de norma constitucional. Os direitos enunciados nos tratados de direitos humanos de que 0 Brasil é parte integram, portanto, o elenco dos direitos constitucionalmente consagrados. Essa conclusão advém ainda de interpretação sistemática e teleológica do Texto, especialmente em face da força expansiva dos valores da dignidade humana e dos direitos fundamentais, como parâmetros axiológicos a orientar a compreensão do fenômeno constitucional. ${ }^{31}$

Nessa seara, Flávia Piovesan entende que, por força do art. $5^{\circ}, \S 2^{\circ}$, da Carta Magna, os direitos enunciados nos tratados internacionais de direitos humanos devem receber o mesmo regime constitucional conferido aos direitos e garantias fundamentais. Contudo, deve-se destacar que este entendimento não é pacifico ${ }^{32}$, aliás, o Recurso Extraordinário no 466343, recentemente julgado pelo STF (2008), entendeu pela hierarquia infraconstitucional, mas supra legal, dos tratados internacionais de direitos humanos, ou seja, eles estariam acima da lei, mas abaixo da Constituição.

Sobre o assunto da hierarquia dos tratados internacionais de direitos humanos, destaca-se a Emenda Constitucional no 45, a qual instituiu o $\S 3^{\circ}$, do art. 5․ Em tese, a edição dessa norma deveria ter acalentado os debates sobre o assunto, contudo, não foi isso que ocorreu. Estabeleceu-se, com este dispositivo legal, que os tratados internacionais de direitos humanos são equivalentes a emendas constitucionais, desde que aprovados em cada casa do Congresso Nacional, em dois turnos, por três quintos dos votos dos respectivos membros. Entretanto, o debate permaneceu latente "para a hipótese dos inúmeros tratados que foram aprovados antes da vigência da referida norma e constituem a grande maioria da legislação de direito internacional de direitos humanos"33, bem como para aqueles tratados que não cumprem com os requisitos exigidos na Emenda no 45 .

Entende-se que o $\S 3^{\circ}$, do art. 5ำ, da Carta de 1988, não revogou o disposto no $\S 2^{\circ}$, razão porque este último dispositivo ainda continua a ter aplicação irrestrita, sendo 0 § $3^{\circ}$ apenas uma regra interpretativa do $\S 2^{\circ}$. Assim, há que se considerar como direitos formalmente fundamentais os dispositivos constantes das Convenções Internacionais, uma vez que, consoante destaca Miranda Arruda, é impossível não reconhecer que essas normas não consagram direitos fundamentais. ${ }^{34}$

Na mesma linha, Flávia Piovesan conclui: "os direitos constantes dos tratados internacionais integram e complementam o catálogo de direitos constitucionalmente previstos, o que justifica estender a esses direitos o regime conferido aos demais direitos e garantias fundamentais" ${ }^{35}$. Do mesmo modo que os direitos e garantias fundamentais têm aplicação imediata, nos moldes do $\S 1^{\circ}$, do art. $5^{\circ}$, da Carta Constitucional, assim também as normas internacionais de direitos humanos 0 teriam, merecendo especial observância e imediata aplicação pelo Estado.

Oportuno, contudo, indagar-se: que norma aplicar em caso de eventual conflito entre as regras nacionais e internacionais? Sobre o assunto, a doutrina vem 
entendendo que, em se tratando de direitos humanos, "há de prevalecer sempre a regra mais favorável ao sujeito de direito, pois a proteção da dignidade da pessoa humana é a finalidade última e a razão de ser de todo o sistema jurídico" ${ }^{36}$. Não há mais o que se falar em incompatibilidade entre normas, eis que os dois planos se unem com a finalidade de assegurar maior proteção jurídica ao cidadão. Daí dizer que "as normas nacionais e internacionais não coexistem em um sentido de exclusão, mas, ao contrário, interagem complementando-se reciprocamente"37.

Cançado Trindade assevera que "compreendeu-se, pouco a pouco, que a proteção aos direitos básicos da pessoa humana não se esgota, como não poderia esgotar-se, na atuação do Estado, na pretensa e indemonstrável competência nacional exclusiva"38, e é justamente essa abertura constitucional ao direito internacional, com a transformação da 'soberania nacional', que marca o constitucionalismo contemporâneo. Essa abertura permite uma maior democratização e exercício da cidadania pelos sujeitos de direito, os quais passam a sê-lo, também, no âmbito internacional. Além de permitir a intensificação das respostas jurídicas em caso de violação a direitos humanos, o aparato internacional inova também a ordem jurídica interna, complementando e integrando os direitos já consagrados. $^{39}$

Para exemplificar a influência do Direito Internacional dos Direitos Humanos no plano interno dos países, analisaremos como a Corte Européia de Direitos Humanos vem se posicionando em relação aos direitos dos cidadãos europeus no que toca à razoável duração do processo, e a forma como os países membros da Convenção Européia vêm respondendo às exigências da Corte.

\section{O DIREITO À RAZOÁVEL DURAÇÃO DO PROCESSO NA CONVENÇÃO EUROPÉIA DE DIREITOS HUMANOS}

A Convenção Européia de Direitos Humanos foi elaborada no âmbito do Conselho da Europa, criado em 05 de maio de 1949, depois da Segunda-Guerra Mundial, com o objetivo de unificar o continente europeu ${ }^{40}$. Os países membros desse Conselho adotaram a Convenção Européia para a Proteção dos Direitos Humanos e das Liberdades Fundamentais (CEDH) em 04 de novembro de 1950, contudo, esta entrou em vigor apenas em 1953, com sua ratificação por 08 Estados $^{41}$, os quais, em 2005 já somavam 45. Na época de sua criação, o continente europeu vivia "a insegurança do pós-guerra, e a fundação do Conselho, com sede em Strasburgo, era vista como alternativa para desenvolver a cooperação entre os Estados e aumentar a unidade entre eles, prevenindo novos conflitos" ${ }^{42}$. A Convenção nasce como resposta aos horrores da Segunda-Guerra, com "a perspectiva de estabelecer parâmetros protetivos mínimos atinentes à dignidade humana"43.

Samuel Miranda Arruda aduz que a Carta é o primeiro documento de âmbito regional a prever a criação de órgãos supranacionais com a competência para julgar os casos de violação de direitos humanos consagrados em seu texto. Por esta razão, o seu desenvolvimento foi notável ${ }^{44}$, sendo considerado o mais consolidado e amadurecido dos sistemas regionais de direitos humanos, exercendo grande influência sobre o sistema interamericano e africano. ${ }^{45} \mathrm{~A}$ partir de então, o cidadão 
passa a ser um sujeito de direito internacional, o qual "contrai direitos e obrigações perante a comunidade internacional e é capaz de vindicá-los em um Tribunal Internacional” ${ }^{46}$. Essa proteção internacional tem dupla importância:

[...] por um lado, ela representa a possibilidade concreta de justiça material nos casos em que, devido principalmente a questões processuais, esta não seria mais alcançada no âmbito interno dos Estados; por outro, juntamente com a incorporação formal da CEDH na legislação interna dos Estados, a análise dos casos individuais vem corrigindo, aos poucos, as deficiências dos ordenamentos jurídicos nacionais, e estabelecendo um real standard mínimo comum de proteção dos indivíduos. ${ }^{47}$

O cidadão europeu passou, então, a ter a possibilidade de socorrer-se à Corte Européia de Direitos Humanos para salvaguardar os direitos consagrados no texto a Convenção Européia. Assim, o indivíduo pode hoje apresentar petição diretamente à Corte Européia para denunciar a violação a algum direito humano constante da Convenção por seu Estado. Esse direito de petição dos indivíduos diretamente à Corte, sem passar pela análise da extinta Comissão Européia de Direitos

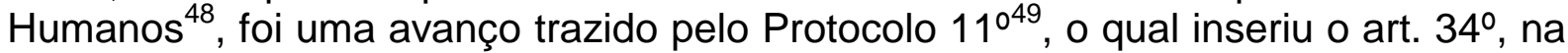
Convenção Européia, o qual dispõe sobre o novo direito de petição, veja-se:

Art. 34. A Corte pode receber petições de qualquer pessoa, organização não governamental ou grupo de indivíduos que se considere vítima de violação por qualquer Alta Parte Contratante dos direitos reconhecidos na Convenção ou nos seus protocolos. As Altas Partes Contratantes comprometem - se a não criar qualquer entrave ao exercício efectivo desse direito.

Consoante entendimento de Viana, o advento do Protocolo $11^{\circ}$ foi "um grande avanço na luta pela efetivação dos direitos humanos e um presente a todos os indivíduos que agora possuem o direito de postular e reivindicar suas garantias diretamente ao Tribunal Europeu" ${ }^{\prime 2}$. Contudo, ao mesmo tempo em que significou um grande avanço, o protocolo em questão também trouxe um desafio à Corte Européia, ante ao aumento significativo das demandas que passaram a ser ajuizadas. Miranda Arruda informa que "enquanto em 1988 foram submetidas e registradas 1.013 queixas individuais, em 2000 este número chegou a $10.486 " 51$. Na mesma linha, Bonello arremata:

\footnotetext{
Hoje mais de 800 milhões de pessoas têm acesso à Corte na Europa (...). A Corte é hoje vítima de seu próprio sucesso, com estrutura e recursos insuficientes para enfrentar o volume diário de demandas - 39.000 novas demandas apenas em 2003. Enquanto nos 45 primeiro anos de sua existência (antes das reformas de 1998), a Corte e a Comissão tinham proferido no total 38.389 julgamentos, a nova Corte já recebeu 61.633 casos em cinco anos. [...]. ${ }^{52}$
}

A reivindicação dos cidadãos perante a Corte Européia, denunciando os Estados pela violação ao direito à razoável duração do processo se tornou demanda comum $^{53}$, eis que a Convenção prevê em seu art. $6^{\circ}, \S 1^{\circ 54}$, que qualquer pessoa tem direito a que a sua causa seja examinada num prazo razoável por um Tribunal independente e imparcial, seja em matéria civil ou penal. Essa proteção, além de 
garantir ao indivíduo uma justa indenização pela excessiva duração do processo, exige dos Estados a adoção de medidas para evitar a reiteração do descumprimento, influenciando diretamente na forma de atuação dos países e também na legislação nacional.

Para melhor compreender a responsabilização dos Estados perante a Corte Européia, traz-se algumas informações sobre sua atuação, competência e sistema de decisões. Inicialmente, cumpre dizer que ela é composta por um número de juízes igual ao número de Estados-partes, os quais devem gozar da mais alta reputação moral e possuir condições para o exercício de altas funções judiciais ou devem ser juristas de reconhecida competência (art. 21, da Convenção). Eles são eleitos pela Assembléia do Parlamento, com base em uma lista tríplice apresentada por cada Estado e têm mandato de seis anos, sendo reelegíveis (arts. 22 e 23, da Convenção).

Quanto à sua competência, a Corte Européia possui tanto a competência consultiva, como a contenciosa. Enquanto a segunda mostra-se extremamente desenvolvida, a primeira é deficitária, especialmente pela restrição contida no art. 47, da Convenção, que prevê que as opiniões consultivas não devem referir-se a questões relativas ao conteúdo ou à extensão dos direitos e liberdades constantes da Convenção e seus protocolos, nem a outras questões que a Corte ou o Comitê de Ministros possa levar em consideração em decorrência de sua competência. ${ }^{55}$

No plano contencioso, qualquer pessoa, organização não governamental ou grupo de indivíduos têm acesso à Corte, podendo apresentar petição, denunciando a violação a um direito humano protegido. Recebida a petição, a Corte analisará, preliminarmente, se os requisitos de admissibilidade constantes do art. 35 , foram devidamente cumpridos, quais sejam:

\begin{abstract}
a) esgotamento prévio de recursos internos; b) observância do prazo de 6 meses, a contar da data da decisão definitiva; c) não ser anônima; d) inexistência de litispendência internacional; e f) não constituir em abuso de direito de petição. Além disso, o Estado denunciado como violador deve ser parte da Convenção. ${ }^{56}$
\end{abstract}

Dos requisitos supra, infere-se que a atuação da Corte Européia é subsidiária e complementar, ou seja, para o protocolo de uma petição no plano internacional é preciso que 0 indivíduo tenha esgotado os meios internos de defesa. Isso porque a Convenção confere aos Estados a incumbência à proteção desses direitos ${ }^{57}$, devendo constituir a Corte meio subsidiário de proteção.

Sendo a petição declarada inadmissível, não haverá recurso que modifique essa decisão, contudo, se for considerada admissível, as partes serão informadas pela Corte, que buscará uma solução amistosa. ${ }^{58}$ Havendo resolução amigável do conflito, arquivar-se-á o assunto e será proferida uma decisão, a qual conterá uma breve exposição dos fatos e a solução adotada (art. 39, da Convenção). Contudo, em não havendo conciliação, a Corte abrirá prazo para a apresentação de memoriais e decidirá sobre a necessidade de realização de audiência. Em se entendendo pela violação de algum direito previsto na Convenção, embora as 
sentenças da Corte tenham natureza declaratória, poderá esta determinar a compensação pecuniária à vítima, nos moldes do art. 41, bem como medidas gerais, como reformas administrativas, alterações nas práticas judiciais, etc. ${ }^{59}$

Conforme previsão do art. 46, da Convenção, cabe ao Comitê de Ministros supervisionar o cumprimento das decisões proferidas pela Corte, cabendo a cada Estado-parte informar ao referido Comitê o cumprimento das medidas impostas na decisão. Em caso de não cumprimento, "a sanção última a ser aplicada ao Estado violador é a ameaça de expulsão do Conselho da Europa, com fundamento nos artigos $3^{\circ}$ e $8^{\circ}$ do Estatuto do Conselho"60. Flávia Piovesan aponta que a atuação do Comitê de Ministros vem sendo satisfatória e que pressões de natureza diversa vêm encorajando os Estados ao cumprimento das decisões. ${ }^{61}$

Miranda Arruda aduz que as petições que versam sobre a violação do direito à razoável duração do processo são as demandas que mais se verificam na Corte Européia, o que se constata a partir dos dados dos anos de 1995 até 1999, que revelam que das 5.307 reclamações, 3.129 (58,95\%) referiam-se à razoabilidade temporal dos procedimentos ${ }^{62}$. E, em razão das reiteradas demandas nesse sentido, a Corte Européia apresenta hoje uma vasta jurisprudência sobre o assunto, já tendo pacificado o entendimento de que, em havendo irracional duração do processo, o Estado violador do direito tem a obrigação de reparar os danos sofridos pela vítima.

A Corte Européia já firmou posicionamento sobre o que entende por 'tempo razoável': "é conseqüentemente impossível descrever um período particular como razoável ou, por outro lado, descrever o não razoável em abstrato" ${ }^{63}$. Já deixou claro, em várias ocasiões, que "a razoabilidade do período deve ser determinada à luz de circunstâncias particulares de cada caso"64. Contudo, vem estabelecendo alguns critérios para analisar a questão da 'razoabilidade' em cada caso em concreto, os quais possibilitam a redução do arbítrio e tornam factível o enfrentamento da complexidade da matéria, veja-se: a) a complexidade da causa, b) o comportamento das partes, e c) 0 modo como as autoridades dirigiram 0 processo. $^{65}$

Carlos Henrique Ramos sintetiza os critérios desenvolvidos pela Corte Européia, afirmando que a garantia à razoável duração do processo está sendo violada quando:

a) em uma causa considerada não complexa, a controvérsia não seja solucionada tempestivamente ou, em se tratando de um feito que verse sobre questões complexas, os juízes não empreendam esforços para o seu adequado enfrentamento;

b) os postulados éticos de demandar e ser demandado, além dos deveres típicos de colaboração, não sejam obedecidos;

c) os deveres dos juízes e dos auxiliares da justiça, mais precisamente aqueles relacionados com a correta condução do processo e com o cumprimento dos prazos, não sejam corretamente obedecidos;

d) o Estado, como um todo, não adote providências estruturais para melhor aparelhar o sistema judiciário. ${ }^{66}$ 
A complexidade da causa, bem como a conduta das partes, influencia diretamente no tempo de uma demanda. Igualmente, a conduta dos juízes, auxiliares da justiça, promotores, etc., contribui para a demora excessiva do processo. A doutrina tem entendido, à luz da jurisprudência da Corte Européia, que a duração de um processo normal seria de aproximadamente 3 anos. ${ }^{67} \mathrm{E}$ mesmo considerando toda a complexidade, contratempos e dificuldades que a causa venha a apresentar, não se justifica o fato de um processo durar mais de 10 anos. ${ }^{68}$

Vejamos, pois, alguns julgados da Corte Européia:

Corte Europea dei Diritti dell'Uomo (Strasburgo). Caso Lugnan In Basile contro Italia. Sentenza del 19 febbraio 2002 Ricorso $n^{\circ}$ 56207/00. Violazione del termine ragionevole di durata di un processo amministrativo (articolo 6 \& 1 della Convenzione) proposto da un pubblico dipendente avente ad oggetto la retrodatazione dell'anzianità di servizio ed il pagamento di crediti di lavoro; un grado di giudizio, dodici anni e due mesi, compresa la fase di esecuzione di una prima sentenza interlocutoria che aveva ordinato la produzione di documenti e nominato un Commissario ad acta. Equa soddisfazione liquidata in 18.000 (diciottottomila) Euro per il danno morale e 2000 (duemila) Euro per le spese legali. ${ }^{69}$

Corte Europea dei Diritti dell'Uomo (Strasburgo) CASO MASTROMAURO S.R.L. contro ITALIA SENTENZA del 28 marzo 2002 Ricorso n 47479/99 Violazione del termine ragionevole di durata di un processo civile (articolo 6 della Convenzione) avente ad oggetto un'azione di revocatoria fallimentare a carico di una società commerciale: nove anni e sei mesi per tre gradi di giudizio. Liquidazione di 3.000 EUR (tre mila euro) per danno morale e 500 EUR (cinquecento euro) per spese legali, a favore della società commerciale ricorrente a Strasburgo. ${ }^{70}$

A Itália é o país que lidera o ranking de violadores da garantia. Entre os anos de 1999 e 2006, a média dos violadores se encontrava entre 200 condenações, enquanto a Itália contava com uma média de 900 nesse mesmo período.$^{71}$ Diante das inúmeras condenações sofridas, em 2001, o país editou a Legge Pinto (Lei 89/2001), a qual veio a garantir o direito dos cidadãos a receber indenização em caso de violação à garantia da razoável duração do processo. Piovesan informa que medidas legislativas nesse sentido também foram adotadas nos Países Baixos e na Suécia ${ }^{72}$ o que demonstra a influência que os julgados da Corte têm no direito interno dos países europeus.

\section{LEGGE PINTO (89/2001) - INFLUÊNCIA INTERNACIONAL DA CORTE EUROPÉIA DE DIREITOS HUMANOS NO PLANO NACIONAL - ITÁLIA}

Paulo Hoffman esclarece que os recursos dos cidadãos italianos perante a Corte Européia causaram um enorme transtorno ao país, o qual passou a sofrer pressão dos demais Estados-membros da Comunidade Européia para que fosse cumprido o regramento em questão. Hoffman informa que também houve pressão da própria Corte Européia, a qual encontrava dificuldade em julgar os seus próprios processos em tempo adequado. Assim, a Itália se viu obrigada a introduzir o "processo justo"73 em sua Constituição e editar uma lei prevendo a possibilidade dos cidadãos reivindicarem indenização perante suas próprias Cortes, restringindo, 
assim, o acesso direto à Corte Européia, que exige o esgotamento prévio dos recursos internos. ${ }^{74}$

No que toca à da Legge Pinto (Lei 89/2001), o seu art. $2^{\circ}$, assim dispõe:

Art. 2. Diritto all'equa riparazione

1. Chi ha subito un danno patrimoniale o non patrimoniale per effetto di violazione della Convenzione per la salvaguardia dei diritti dell'uomo e delle libertà fondamentali, ratificata ai sensi della legge 4 agosto 1955, n. 848, sotto il profilo del mancato rispetto del termine ragionevole di cui all'articolo 6 , paragrafo 1, della Convenzione, ha diritto ad una equa riparazione.

2. Nell'accertare la violazione il giudice considera la complessità del caso e, in relazione alla stessa, il comportamento delle parti e del giudice del procedimento, nonché quello di ogni altra autorità chiamata a concorrervi o a comunque contribuire alla sua definizione.

3. II giudice determina la riparazione a norma dell'articolo 2056 del codice civile, osservando le disposizioni seguenti:

a) rileva solamente il danno riferibile al periodo eccedente il termine ragionevole di cui al comma 1 ;

b) il danno non patrimoniale è riparato, oltre che con il pagamento di una somma di denaro, anche attraverso adeguate forme di pubblicità della dichiarazione dell'avvenuta violazione. ${ }^{75}$

Consoante se infere, o direito a indenização decorre de danos morais e materiais sofridos durante a excessiva duração do processo, havendo clara disposição no texto de que se trata "da mesma indenização a que o cidadão teria direito com base na Convenção Européia de Direitos do Homem" "76. A Lei deixa claro que os critérios utilizados pelo juiz quando da análise do pedido são os mesmos definidos pela Corte Européia, quais sejam: a complexidade do caso, o comportamento das partes, do juiz e demais auxiliares. A reparação de danos, por sua vez, segue os ditames da lei interna, podendo o dano moral ser reparado por indenização pecuniária ou publicidade. ${ }^{77}$

Outro aspecto interessante da Legge Pinto é que existe a possibilidade da demanda indenizatória ser proposta ainda que pendente o processo em que se julga ter havido violação à razoável duração, contudo, a ação indenizatória tem o prazo prescricional de seis meses, a contar do trânsito em julgado da decisão ${ }^{78}$. 0 art. $5^{\circ}$, da referida lei, determina que as decisões devem ser comunicadas às partes e também ao Procurador-Geral da Corte dei conti, que é uma espécie de órgão administrativo responsável por controle dos gastos públicos, para o fim de eventual verificação de culpa das autoridades envolvidas. Isso demonstra a preocupação do legislador em tomar medidas disciplinares e evitar reincidência. ${ }^{79}$

Sem a pretensão de esgotar o tema, quer-se apenas deixar registrada a influência que os julgados da Corte Européia de Direitos Humanos vêm tendo no âmbito interno dos países europeus, e a forma como a Corte vem contribuindo para a efetivação desses direitos, em especial ao direito à razoável duração do processo na Itália. As deliberações da Corte, além do caráter punitivo, "objetivam despertar nos governantes e nos administradores da Justiça uma responsabilidade que estes já deveriam, de fato, ter assumido ao aderir à Convenção. Ademais, estimulam que soluções estruturais sejam buscadas internamente" 80 . 


\section{O DIREITO À RAZOÁVEL DURAÇÃO DO PROCESSO NA CONVENÇÃO AMERICANA DE DIREITOS HUMANOS}

A Convenção Americana de Direitos Humanos, tardiamente ratificada pelo Brasil - apenas em 1992 - também denominada Pacto de San José da Costa Rica foi assinada em San José, Costa Rica, em 1969, mas entrou em vigor apenas em $1978^{81}$. Apenas Estados-membros da Organização dos Estados Americanos (OEA) têm direito de aderir à Convenção ${ }^{82}$. A Convenção Americana, diferentemente da Européia, nasce em uma região marcada pela exclusão, desigualdade social, na qual se "convive com as reminiscências do legado dos regimes autoritários ditatoriais, com uma cultura de violência e de impunidade, com a baixa densidade de Estados de Direito e com a precária tradição de respeito aos direitos humanos no âmbito doméstico" ${ }^{83}$.

O referido documento internacional em muito de espelha na Convenção Européia, assim como acontece com os precedentes da Corte Européia. Contudo, a jurisprudência da Corte Interamericana sobre a questão da razoável duração do processo ainda não é tão vasta, quiçá, porque, consoante enfatiza Miranda Arruda, "o Tribunal das Américas ocupou-se principalmente de casos de morte, tortura, e desaparecimentos enquanto na Europa pontificam as lesões aos direitos processuais fundamentais" ${ }^{\prime 4}$. Apesar disso, o autor destaca que isso não quer dizer que as violações a direitos processuais também não ocorram no espaço americano.

A principal diferença entre o sistema europeu e o interamericano é a legitimação para apresentar petição à Corte. Enquanto no âmbito europeu o cidadão pode apresentar reclamação diretamente à Corte, no âmbito interamericano esta deve ser encaminhada à Comissão de Direitos Humanos. Entende-se que o direito de petição garante maior efetividade ao sistema europeu, eis que "ao garantir que os indivíduos encaminhem as suas próprias reclamações, o direito da petição individual torna a efetividade dos direitos humanos menos dependente de considerações políticas outras, que tendam a motivar uma ação ou inação governamental"85.

A Convenção Americana é implementada por dois órgãos, quais sejam: a Comissão Interamericana de Direitos Humanos ${ }^{86}$ e a Corte Interamericana de Direitos Humanos. Dentre outras funções ${ }^{87}$, a Comissão Interamericana deve examinar, em juízo de admissibilidade, as petições encaminhadas pelos indivíduos, grupos de pessoas, ou entidades não governamentais, que contenham denúncia de violação aos direitos previstos na Convenção, nos termos do art. 44, 'f'. As petições apenas podem ser admitidas e examinadas se forem apresentadas por um Estadoparte que haja feito uma declaração reconhecendo a competência da Comissão. Ademais, as petições devem cumprir com os requisitos de admissibilidade do art. 46, os quais seguem transcritos abaixo:

a) que hajam sido interpostos e esgotados os recursos da jurisdição interna, de acordo com os princípios de Direito Internacional geralmente reconhecidos; 
b) que seja apresentada dentro do prazo de seis meses, a partir da data em que o presumido prejudicado em seus direitos tenha sido notificado da decisão definitiva;

c) que a matéria da petição ou comunicação não esteja pendente de outro processo de solução internacional; e

d) que, no caso do art. 44, a petição contenha o nome, a nacionalidade, a profissão, o domicílio e a assinatura da pessoa ou pessoas ou do representante legal da entidade que submeter a petição.

Consoante dispõe o texto da Convenção, no mesmo art. 46, nos casos em que: a) não existir na legislação interna do Estado o devido processo legal para a proteção do direito que se alegue tenha sido violado; b) não tenha se permitido ao prejudicado o acesso aos recursos da jurisdição interna, ou tenha este sido impedido de esgotá-los; ou, c) se houver demora injustificada na decisão sobre os mencionados recursos; os requisitos 'a' e 'b', acima transcritos, ficam dispensados. Isso é importante para o tema em questão, porque "no caso de violação à razoável duração do processo, como muitos países americanos não possuem procedimentos para que esta violação seja responsavelmente indenizada, o requisito de esgotar os recursos da jurisdição interna não é válido"88.

Reconhecida a admissibilidade da petição, a Comissão solicitará informações ao Estado, e, recebidas as informações ou transcorrido o prazo fixado pela Comissão, esta verificará se subsistem os motivos da petição. Em não existindo os motivos, a petição será arquivada, contudo, se isso não ocorrer, a Comissão investigará a matéria e as provas apresentadas, podendo realizar audiência com os representantes das partes, e, ainda, uma investigação in loco do assunto. ${ }^{89} \mathrm{Em}$ não havendo composição amistosa entre as partes ${ }^{90}$, a Comissão elaborará um relatório, expondo os fatos e suas conclusões, no qual poderá formular recomendações, as quais entender convenientes.

Após o envio do informe, se a Comissão julgar ser a melhor atitude para prevalência dos direitos humanos, poderá encaminhar o caso à Corte Interamericana de Direitos Humanos, para julgamento, desde que o Estado tenha aceitado a sua jurisdiçã $0^{11}$. Entretanto, se o assunto não tiver sido solucionado ou encaminhado à Corte pela Comissão ou pelo Estado no prazo de três meses, a Comissão poderá emitir, pelo voto da maioria de seus membros, opinião e conclusões sobre o caso, fixando prazo para que o Estado cumpra as recomendações fixadas. Vencido o prazo imposto, a Comissão decidirá, por maioria de seus membros, se o Estado cumpriu as recomendações, e publicará o informe por ela elaborado no relatório anual de suas atividades. ${ }^{92}$

A Corte Interamericana de Direitos Humanos, com sede oficial em San José, Costa Rica, foi instituída em 1979, e tem o objetivo de aplicar e interpretar a Convenção Americana de Direitos Humanos. Assim como a Corte Européia, a Interamericana tem função consultiva ${ }^{93}$ e contenciosa, sendo que, em matéria consultiva, tem mais ampla jurisdição do que a Européia. Assim, vem contribuindo para o desenvolvimento de análises aprofundadas a respeito do alcance e impacto da Convenção Americana ${ }^{94}$. No plano contencioso, a competência da Corte se limita aos Estados-partes que reconheçam a sua jurisdição expressamente ${ }^{95}$ (art. 62, da Convenção), o que, segundo Cançado Trindade, significa um "anacronismo histórico, 
que deve ser superado, a fim de que se consagre o autoritarismo da jurisdição obrigatória da Corte para todos os Estados-partes da Convenção"96.

A Corte Interamericana tem competência para conhecer de casos relativos à interpretação e aplicação das disposições da Convenção Americana. Nos julgamentos, se entender que houve violação a um direito ou liberdade protegida, pode determinar as medidas necessárias para que se assegure ao prejudicado o exercício do direito violado, bem como pode impor ao Estado o pagamento de indenização justa à parte lesada, consoante prevê o art. 63, da Convenção. A sentença da Corte será definitiva e inapelável. Em relação à parte da sentença que determina indenização compensatória, poderá o beneficiário executá-la no país respectivo, por meio do processo interno do país para a execução de sentenças contra o Estado (art. 68, da Convenção). Quanto ao cumprimento das sentenças, necessário destacar que:

[...] o sistema americano carece de mecanismos e de um órgão concreto para fiscalizar a sua execução, como o Comitê de Ministros do Conselho da Europa. No sistema americano, existe tão somente a previsão de a Corte indicar, em seus informes anuais à Assembléia Geral, os casos em que um Estado não tenha dado cumprimento às sentenças. ${ }^{97}$

No que toca ao direito à razoável duração do processo, este também se encontra previsto no art. $8^{\circ}$, ' 1 ', da Convenção Americana ${ }^{98}$, e no art. $7^{\circ}$, ' $5^{\prime 99}$. Em caso de violação a esses preceitos, poderá o prejudicado recorrer à proteção internacional, por meio de petição destinada à Comissão Interamericana de Direitos Humanos. Afigura-se que os operadores do direito devem buscar o cumprimento desses preceitos perante a Comissão Interamericana, já que o Pacto San José da Costa Rica foi devidamente ratificado pelo Brasil, tendo as suas normas aplicação imediata, por força do art. $5^{\circ}, \S 2^{\circ}$, da Constituição Federal, consoante já analisado neste trabalho.

Apesar de a jurisprudência da Corte Interamericana não ser tão vasta como a da Européia no que toca ao tema da razoável duração do processo, o órgão já se pronunciou sobre a matéria em algumas situações. Para Cançado Trindade, a garantia se tornará cada vez mais reconhecida, porquanto "a Corte Interamericana de Direitos Humanos está sendo convocada freqüentemente a pronuncia-se sobre casos de violações ao direito a um processo justo e rápido" ${ }^{100}$.

A Corte Interamericana utiliza-se dos mesmos critérios utilizados pela Corte Européia para definir a razoabilidade do tempo do processo, contudo, ao contrário da Corte Européia, que entende que um prazo de três anos é o tempo normal de um processo, a Corte Interamericana assim já se pronunciou: "La Corte ha estabelecido el critério de que un periodo de cinco anos transcurrido desde el momento del auto de apertura del poceso rebasada los limites de la razonablidad"101, ou seja, entende que o tempo de cinco anos, contados da abertura do processo, é o tempo razoável de um processo comum, sem dilações indevidas.

Posto isso, e sem a pretensão de esgotar o tema, traremos dois julgados da Comissão/Corte Interamericana de Direitos Humanos, para demonstrar a atuação 
dos referidos órgãos internacionais, e exemplificar a aplicação do direito à razoável duração do processo. O primeiro caso trata-se da denúncia da Sra. Maria da Penha Maia Fernandes, perante a Comissão Interamericana de Direitos Humanos (2001), a qual alegou que sofreu violência doméstica por 15 (quinze) anos, não tendo o Estado brasileiro tomado as medidas necessárias para processar e punir o seu agressor, apesar das reiteradas comunicações feitas. A Comissão assim se pronunciou:

\section{I - RESUMO:}

1. Em 20 de agosto de 1998, a Comissão Interamericana de Direitos Humanos (doravante denominada "a Comissão") recebeu uma denúncia apresentada pela Senhora Maria da Penha Maia Fernandes, pelo Centro pela Justiça e pelo Direito Internacional (CEJIL) e pelo Comitê LatinoAmericano de Defesa dos Direitos da Mulher (CLADEM) (doravante denominados "os peticionários"), [...]

2. A denúncia alega a tolerância da República Federativa do Brasil (doravante denominada "Brasil" ou "o Estado") para com a violência cometida por Marco Antônio Heredia Viveiros em seu domićlio na cidade de Fortaleza, Estado do Ceará, contra a sua então esposa Maria da Penha Maia Fernandes durante os anos de convivência matrimonial, que culminou numa tentativa de homicídio e novas agressões em maio e junho de 1983. Maria da Penha, em decorrência dessas agressões, sofre de paraplegia irreversível e outras enfermidades desde esse ano. Denuncia-se a tolerância do Estado, por não haver efetivamente tomado por mais de $\mathbf{1 5}$ anos as medidas necessárias para processar e punir 0 agressor, apesar das denúncias efetuadas. Denuncia-se a violação dos artigos 1(1) (Obrigação de respeitar os direitos); 8 (Garantias judiciais); 24 (Igualdade perante a lei) e 25 (Proteção judicial) da Convenção Americana, em relação aos artigos II e XVIII da Declaração Americana dos Direitos e Deveres do Homem (doravante denominada "a Declaração"), bem como dos artigos 3, 4,a,b,c,d,e,f,g, 5 e 7 da Convenção de Belém do Pará. [...]

$[\ldots]$

VIII. RECOMENDAÇÕES

61. A Comissão Interamericana de Direitos Humanos reitera ao Estado Brasileiro as seguintes recomendações:

1. Completar rápida e efetivamente o processamento penal do responsável da agressão e tentativa de homicídio em prejuízo da Senhora Maria da Penha Fernandes Maia.

2. Proceder a uma investigação séria, imparcial e exaustiva a fim de determinar a responsabilidade pelas irregularidades $e$ atrasos injustificados que impediram o processamento rápido e efetivo do responsável, bem como tomar as medidas administrativas, legislativas e judiciárias correspondentes.

3. Adotar, sem prejuízo das ações que possam ser instauradas contra o responsável civil da agressão, as medidas necessárias para que o Estado assegure à vítima adequada reparação simbólica e material pelas violações aqui estabelecidas, particularmente por sua falha em oferecer um recurso rápido e efetivo; por manter o caso na impunidade por mais de quinze anos; e por impedir com esse atraso a possibilidade oportuna de ação de reparação e indenização civil.

4. Prosseguir e intensificar o processo de reforma que evite a tolerância estatal e o tratamento discriminatório com respeito à violência doméstica contra mulheres no Brasil. [.... ${ }^{102}$ (Grifos nossos).

o segundo caso refere-se a denuncia dos familiares do Sr. Ximenes Lopes, o qual foi internado em uma Casa de Repouso e veio a falecer, em razão da violência 
sofrida por parte dos funcionários da Casa três dias após o internamento. A Corte Interamericana aduz que o Estado brasileiro demorou no trâmite da investigação, ação criminal e de reparação civil, veja-se:

\section{I - INTRODUÇÃO DA CAUSA}

1. Em $1^{\circ}$ de outubro de 2004, em conformidade com o disposto nos artigos 50 e 61 da Convenção Americana, a Comissão Interamericana de Direitos Humanos (doravante denominada "Comissão Interamericana" ou "Comissão") submeteu à Corte uma demanda contra a República Federativo do Brasil (doravante denominado "Estado" ou "Brasil"), a qual se originou na denúncia no 12.237, recebida na Secretaria da Comissão em 22 de novembro de 1999.

2. A Comissão apresentou a demanda neste caso com o objetivo de que a Corte decidisse se o Estado era responsável pela violação dos direitos consagrados nos artigos 4 (Direito à Vida), 5 (Direito à Integridade Pessoal), 8 (Garantias Judiciais) e 25 (Proteção Judicial) da Convenção Americana, com relação à obrigação estabelecida no artigo 1.1 (Obrigação de respeitar os direitos) do mesmo instrumento, em detrimento do senhor Damião Ximenes Lopes (doravante denominado "senhor Damião Ximenes Lopes", "senhor Ximenes Lopes" ou "suposta vítima"), portador de deficiência mental, pelas supostas condições desumanas e degradantes da sua hospitalização; pelos alegados golpes e ataques contra a integridade pessoal de que se alega ter sido vítima por parte dos funcionários da Casa de Repouso Guararapes (doravante denominada "Casa de Repouso Guararapes" ou "hospital"); por sua morte enquanto se encontrava ali submetido a tratamento psiquiátrico; bem como pela suposta falta de investigação e garantias judiciais que caracterizam seu caso e o mantém na impunidade. A suposta vítima foi internada em $1^{\circ}$ de outubro de 1999 para receber tratamento psiquiátrico na Casa de Repouso Guararapes, um centro de atendimento psiquiátrico privado, que operava no âmbito do sistema público de saúde do Brasil, chamado Sistema Único de Saúde (doravante denominado "Sistema Único de Saúde" ou "SUS"), no Município de Sobral, Estado do Ceará. O senhor Damião Ximenes Lopes faleceu em 4 de outubro de 1999 na Casa de Repouso Guararapes, após três dias de internação.

$[\ldots]$

DECLARA,

Por unanimidade, que

$[\ldots]$

4. O Estado violou, em detrimento das senhoras Albertina Viana Lopes e Irene Ximenes Lopes Miranda, familiares do senhor Damião Ximenes Lopes, os direitos às garantias judiciais e à proteção judicial consagrados nos artigos 8.1 e 25.1 da Convenção Americana, em relação com a obrigação geral de respeitar e garantir os direitos estabelecida no artigo 1.1 desse tratado, nos termos dos parágrafos 170 a 206 da presente Sentença.

[...]

E DISPÕE,

Por unanimidade, que:

6. O Estado deve garantir, em um prazo razoável, que o processo interno destinado a investigar e sancionar os responsáveis pelos fatos deste caso surta seus devidos efeitos, nos termos dos parágrafos 245 a 248 da presente Sentença.

$[\ldots]$

9. O Estado deve pagar em dinheiro para as senhoras Albertina Viana Lopes e Irene Ximenes Lopes Miranda, no prazo de um ano, a título de indenização por dano material, a quantia fixada nos parágrafos 225 e 226, nos termos dos parágrafos 224 a 226 da presente Sentença. 
10. O Estado deve pagar em dinheiro para as senhoras Albertina Viana Lopes e Irene Ximenes Lopes Miranda e para os senhores Francisco Leopoldino Lopes e Cosme Ximenes Lopes, no prazo de um ano, a título de indenização por dano imaterial, a quantia fixada no parágrafo 238 , nos termos dos parágrafos 237 a 239 da presente Sentença

$[\ldots] .^{103}$ (Grifos nossos).

Analisadas as diferenças entre a Corte Européia e a Corte Interamericana de Direitos Humanos, conclui-se que esta última necessita de aprimoramentos, seja no tocante à democratização do acesso direto do indivíduo, seja no que se refere a uma maior fiscalização no cumprimento das decisões. Para Flávia Piovesan, "ainda que recente seja a jurisprudência da Corte, o sistema interamericano está se consolidando como importante e eficaz estratégia de proteção dos direitos humanos, quando as instituições nacionais se mostram omissas ou falhas" ${ }^{\prime 104}$.

\section{CONCLUSÃO}

Ante a análise apresentada, é possível concluir que apesar de o Brasil ter editado a Emenda Constitucional o 45, a qual instituiu, no art. 5, inciso LXXVIII, o princípio da duração razoável do processo, esta garantia não vem sendo respeitada no plano interno, se tornando, assim, 'letra morta'. Não existem meios internos adequados para reivindicar a sua efetividade, nem mesmo para se ver ressarcido dos danos advindos da demora do processo, ainda que o $\S 1^{\circ}$, do art. $5^{\circ}$, estabeleça que os direitos fundamentais tenham aplicabilidade imediata. Isso vem a desrespeitar toda a lógica constante do texto constitucional, a qual consagra a dignidade da pessoa humana como valor central da República e da ordem jurídica nacional.

Considerando que o Brasil ratificou o Pacto de San José da Costa Rica, o qual prevê em seus art. $7^{\circ}$, '5' e art. $8^{\circ}$, ' 1 ', o direito à razoável duração do processo, e que a Constituição do país, em seu art. 4, II, estabelece o princípio da prevalência dos direitos humanos, o qual tem por escopo abrir a ordem jurídica interna ao sistema internacional de direitos humanos; e o art. $5^{\circ}$, $\S 2^{\circ}$, que incluiu no catálogo de direitos fundamentais garantidos os direitos enunciados nos tratados internacionais em que o Brasil é parte; então, as regras constantes do Pacto de San José têm também aplicabilidade imediata, nos moldes do $\S 1^{\circ}$, do art. $5^{\circ}$, da Constituição. Portanto, cabe ao Brasil respeitar os ditames do referido tratado, incluindo-se, nessa lógica, a efetivação do direito à razoável duração do processo, eis que cabe ao Estado-parte tornar efetivos os direitos enunciados nos tratados em que é parte, com elaboração de disposições de direito interno, sob pena de violar a obrigação jurídica assumida no âmbito internacional, e, sob essa ótica, ser responsabilizado ${ }^{105}$.

À medida que o Estado-parte assume obrigações jurídicas no plano internacional, ele passa a consentir com o monitoramento e fiscalização da comunidade internacional. Em casos de violação a direitos humanos na ordem interna, após o país ter empregado todos os meios disponíveis para a resolução do caso, e, ainda assim, a resposta das instituições nacionais não se mostrarem suficientes ${ }^{106}$, deve o Estado ser responsabilizado pelo descumprimento do 
compromisso assumido. A ação internacional é suplementar e constitui uma garantia adicional do cidadão, que é também sujeito de direito internacional, e, por isso, pode apresentar denuncia à violação de direitos humanos pelo Estado, por não ter este último respeitado os direitos humanos.

Flávia Piovesan ensina que o conceito de cidadania se vê alargado e ampliado na medida em que passa a incluir não apenas os direitos previstos no âmbito interno do país, mas também os direitos internacionalmente previstos em tratados de direitos humanos. Sabe-se hoje que "a realização plena e não apenas parcial dos direitos da cidadania envolve o exercício efetivo e amplo dos direitos humanos, nacional e internacionalmente assegurados"107, e, além disso, "o desconhecimento dos direitos e garantias internacionais importa no desconhecimento de parte substancial dos direitos da cidadania, por significar a privação do exercício de direitos acionáveis e defensáveis na arena internacional”"108.

Conclui-se, portanto, que devem os prejudicados pela excessiva duração do processo buscar o cumprimento do preceito perante a Comissão Interamericana de Direitos Humanos, exercitando o pleno exercício de cidadania e auxiliando o sistema interamericano a dar maior efetividade aos direitos e garantias constantes da Convenção. Desse modo, o cidadão global estará exercendo força no âmbito internacional, para que o Estado violador tome atitudes concretas na implementação de medidas que garantam maior agilidade na entrega da prestação jurisdicional, na forma como já ocorre com a Corte Européia de Direitos Humanos, tendo-se como exemplo as medidas adotadas pela Itália na implementação do direito a um processo justo e rápido.

\section{THE RIGHT TO REASONABLE PROCESS TIMING: INTERNATIONAL COURTING AND THE NEED OF ITS PROTECTION ON NATIONAL BACKGROUND}

\section{ABSTRACT}

This article focuses on Brazil's responsibility on Inter American Human Rights Convention, ratified by our country, showing its mechanisms, difficulties, as well as the aid provided to signatory countries derived from international American system in human rights matters. Its is considered that this system could force the materialization of reasonable process timing, bounding itself to internal law in the aim of guarantee more effectiveness on citizen protection and pressing the Estate urge to take concrete attitudes on implementation measures on jurisdictional service fulfillment. timing.

Keywords: International courting. National Protection. Reasonable process NOTAS 
1 Micheli Pereira. Mestranda em Direito Econômico e Sócio-ambiental pela PUC Paraná. E-mail: micheli.pereira.puc@gmail.com. Endereço: Rücker Curi Advocacia e Consultoria Jurídica. Rua Cândido Lopes, 128, 12ํandar. Centro. CEP 80020-060 - Curitiba-PR, Brasil.

Cláudia Maria Barbosa. Doutora. Prof. Titular do PPGD em Direito Econômico e Sócio-ambiental da PUC Paraná. E-mail: claudia.mr.barbosa@gmail.com. Endereço: Pontifícia Universidade Católica do Paraná, Centro de Ciências Jurídicas e Socais. Av. Imaculada Conceição, 1155, Prado Velho, 80215-910 - Curitiba, PR - Brasil. FARIA, J. E. O desafio do judiciário. Revista USP, Dossiê Judiciário, 1994.

3 KOEHLER, Frederico Augusto Leopoldino. A razoável duração do processo. Salvador: Editora Podium, 2009, p. 97.

4 Idem, p. 98.

5 MUZZUOLI, Valério de Oliveira. Direitos Humanos, Constituição e os Tratados Internacionais. São Paulo: Editora Juarez de Oliveira, 2002, p. 337.

6 ARRUDA, Samuel Miranda. O Direito Fundamental à Razoável Duração do Processo. Brasília: Editora Brasília Jurídica, 2006, p. 132.

7 TRINDADE, Antônio Augusto Cançado. Apud. CHOUKR, Fauzi Hassan. A Convenção Americana dos Direitos Humanos e o Direito Interno Brasileiro: bases para a sua compreensão. São Paulo: Editora Edipro, 2001, p. 11.

8 PIOVESAN, Flávia. Temas de Direitos Humanos. São Paulo: Max Limonad, 2003, p. 344.

9 SILVA. Juracy C. Silva. A responsabilidade do Estado por atos judiciários e legislativos. São Paulo: Editora Saraiva, 1985, p. 118.

10 DELGADO, José Algusto. Apud. KOEHLER, Frederico Augusto Leopoldino. op cit. p. 101.

11 HOFFMAN, Paulo. Apud. VIANA, Adriana Grandinetti, A Razoável Duração do Processo como Mecanismo de Desenvolvimento Social. Dissertação de Mestrado defendida em 2007 na Pontifícia Universidade Católica do Paraná, p. 239.

12 DI PIETRO, Maria Sylvia Zanella. Direito Administrativo. 19. ed.. São Paulo: Editora Atlas, 2006, p. 621.

13 Para Celso Antônio Bandeira de Mello, a responsabilidade estatal é objetiva no caso de conduta lesiva comissiva lícita e subjetiva nos casos de conduta lesiva omissiva e comissiva ilícita. (MELLO, Celso Antônio Bandeira de. Curso de Direito Administrativo. 10ª Edição. São Paulo: Editora Malheiros, 1998, p. 611-635).

DERGINT, Augusto do Amaral. Responsabilidade do Estado por Atos Judiciais. São Paulo: Editora Revista dos Tribunais, 1994, p. 161-162.

15 MELLO, Celso Antônio Bandeira de. op.cit., p. 615.

16 KOEHLER, Frederico Augusto Leopoldino. op cit. p. 102.

17 A responsabilidade do Estado estaria restrita aos casos de erro judiciário em condenação penal e prisão do condenado por tempo superior àquele fixado na sentença, conforme prevê o art. 50, LXXV, da CF. Fora dessas hipóteses, apenas caberia a responsabilização pessoal do magistrado, conforme prevê o art. 133, do CPP.

DERGINT, Augusto do Amaral. op cit, p. 121-157.

19 O STF tem se manifestado reiteradamente no sentido de que não cabe responsabilização do Estado por atos decorrentes do Poder Judiciário, exceto nos casos previstos em lei, veja-se a decisão que segue: EMENTA: Responsabilidade objetiva do Estado. Ato do Poder Judiciário. - A orientação que veio a predominar nesta Corte, em face das Constituições anteriores a de 1988, foi a de que a responsabilidade objetiva do Estado não se aplica aos atos do Poder Judiciário a não ser nos casos expressamente declarados em lei. Precedentes do STF Recurso extraordinário não conhecido. RE 111609 / AM - AMAZONAS. Relator(a): Min. MOREIRA ALVES. Julgamento: 11/12/1992. Órgão Julgador: PRIMEIRA TURMA. Publicação: 19/03/1993. Na mesma linha: RE 429518; RE 228035 e RE 219117.

PIOVESAN, Flávia. Temas de Direitos Humanos, p. 343-345.

Idem, p. 328.

22 PIOVESAN, Flávia. Direitos Humanos e o Direito Constitucional Internacional. 11. ed.. São Paulo: Editora Saraiva, 2009, p. 25.

23 JUSTEN FILHO, Marçal. Empresa, Ordem Econômica e Constituição. Revista de Direito Administrativo no 212. Rio de Janeiro, abril-junho de 1998, p. 117. PIOVESAN, Flávia. Temas de Direitos Humanos. p. 340.

Idem, Ibidem.

PIOVESAN, Flávia. Direitos Humanos e o Direito Constitucional Internacional. p. 39-40.

MUZZUOLI, Valério de Oliveira. op cit. p. 334.

28 Idem, p. 337. 
tem

PIOVESAN, Flávia. Direitos Humanos e o Direito Constitucional Internacional. p. 41.

LAFER, Celso. Apud. PIOVESAN, Flávia. Direitos Humanos e o Direito Constitucional Internacional. p. 41.

Idem, p. 52.

Flávia Piovesan ensina que existem quatro entendimentos quanto à hierarquia dos direitos humanos: a) hierarquia supra-constitucional dos tratados de direitos humanos (os tratados flutuam sobre a ordem constitucional); b) hierarquia constitucional (entendimento sustentado pela autora); c) hierarquia infraconstitucional, mas supra-legal (entendimento do STF); d) paridade hierárquica entre tratado e lei federal.

ARRUDA, Samuel Miranda. op. cit. p. 165.

Idem, p. 170.

PIOVESAN, Flávia. Direitos Humanos e o Direito Constitucional Internacional. p. 58.

COMPARATO, Fábio Konder. A Afirmação Histórica dos Direitos Humanos. 2ª Edição. São Paulo: Editora Saraiva, 2001, p. 59-60.

ARRUDA, Samuel Miranda. op. cit. p. 171.

TRINDADE, Antônio Augusto Cançado. A Proteção Internacional dos Direitos Humanos. São Paulo: Editora Saraiva, 1991, p. 4.

PIOVESAN, Flávia. Direitos Humanos e o Direito Constitucional Internacional. p. 358.

PIOVESAN, Flávia. Direitos Humanos e Justiça Internacional. São Paulo: Editora Saraiva, 2007, p. 65.

Os oito Estados-partes que ratificaram a Convenção Européia de Direitos Humanos desde o início eram: Dinamarca, República Federal da Alemanha, Islândia, Irlanda, Luxemburgo, Noruega, Suécia e Reino Unido (Idem, p. 65).

GODINHO, Fabiana de Oliveira. A Proteção Internacional dos Direitos Humanos. Belo Horizonte: Editora Del Rey, 2006, p. 47.

PIOVESAN, Flávia. Direitos Humanos e Justiça Internacional. p. 63.

ARRUDA, Samuel Miranda. op. cit. p. 141-142.

PIOVESAN, Flávia. Direitos Humanos e Justiça Internacional. p. 63.

GODINHO, Fabiana de Oliveira. op. cit. p. 51.

Idem, Ibidem.

Flávia Piovesan explica que, originariamente, a Convenção Européia de Direitos Humanos instituiu como órgãos de monitoramento a Comissão Européia de Direitos Humanos e a Corte Européia de Direitos Humanos e que "as comunicações individuais e interestatais eram submetidas à Comissão Européia de Direitos Humanos, que era um órgão formado por experts independentes. A Comissão decidia se a comunicação era admissível para o exame de mérito. Se a Comissão admitisse a petição, passava então a apreciar os fatos e os argumentos jurídicos e, se uma solução amistosa não fosse alcançada, adotava um relatório indicando se o Estado violou efetivamente a Convenção. Após a elaboração do relatório, que não era vinculante, o caso poderia ser submetido pela Comissão à Corte Européia de Direitos Humanos. Se o caso não fosse submetido à Corte, poderia ser decidido pelo Comitê de Ministros do Conselho da Europa, que é composto por representantes dos Estados-partes. Em qualquer das hipóteses, a decisão era juridicamente vinculante no âmbito do direito internacional" (PIOVESAN, Flávia. Direitos Humanos e Justiça Internacional. p. 71-72).

Protocolo no 11 entrou em vigor em 1ํ de novembro de 1998.

VIANA, Adriana Grandinetti. op. cit. p. 146.

ARRUDA, Samuel Miranda. op. cit. p. 151.

BONELLO, Giovanni. Apud. PIOVESAN, Flávia. Direitos Humanos e Justiça Internacional. p. 74.

Samuel Miranda Arruda assevera que as reclamações de violação do direito ao processo em tempo razoável talvez sejam as maiores responsáveis pela demora dos processos julgados pela Corte Européia, razão porque conclui que "seria importante que as instâncias nacionais procurassem incorporar às suas práticas a noção de razoabilidade temporal gizada pela Cote Européia, de maneira que fosse cada vez menos necessário o recurso à jurisdição supranacional" (ARRUDA, Samuel Miranda. op. cit. p. 152).

54 Artigo $6^{\circ}, \S 1^{\circ}$ da Convenção Européia: "Qualquer pessoa tem direito a que a sua causa seja examinada, equitativa e publicamente, num prazo razoável por um tribunal independente e imparcial, estabelecido pela lei, o qual decidirá, quer sobre a determinação dos seus direitos e obrigações de caráter civil, quer sobre o fundamento de qualquer acusação em matéria penal dirigida contra ela. $\mathrm{O}$ julgamento deve ser público, mas o acesso à sala de audiências pode ser proibido à imprensa ou ao público durante a totalidade ou parte do processo, quando a bem da moralidade, da ordem pública ou da segurança nacional numa sociedade democrática, quando os 
interesses de menores ou a proteção da vida privada das partes no processo o exigirem, ou, na medida julgada estritamente necessária pelo tribunal, quando, em circunstâncias especiais, a publicidade pudesse ser prejudicial para os interesses da justiça". de ração de um processo administrativo ( $\S 1^{\circ}$ do art. $6^{\circ}$ da Convenção) proposto por um funcionário público que tem como objetivo o pagamento de créditos do trabalho; durando o
processo doze anos e dois meses, o que compreendeu a fase da execução de uma primeira processo doze anos e dois meses, o que compreendeu a fase da execução de uma primeira
sentença. A satisfação justa líquida em 18.000 Euros para os danos morais e em 2.000 Euros para os advogados das despesas". (Tradução: VIANA, Adriana Grandinetti. op. cit. p. 165. Disponível no site: http://www.dirittiuomo.it/Corte\%20Europea/ltalia/2002/Lugnan.htm. Acesso em 06/02/2010).

"Corte Européia dos Direitos do Homem (Strasburgo). Caso Mastromauro contra a Itália. Sentença de 28 março 2002. Recurso $n^{\circ}$ 47479. Resta configurada a violação do tempo razoável de duração de um processo civil (art. 6으 da Convenção) que tem como objeto uma ação revocatória de um falido e demora de nove anos e seis meses para três graus de julgamento. Liquidação de 3.000 EUR para danos morais e de 500 EUR para advogados das despesas". (Tradução: VIANA, Adriana Grandinetti. op. cit. p. 165 . Disponível no site: http://www.dirittiuomo.it/Corte\%20Europea/Italia/2002/Mastromauro.htm. Acesso em 06/02/2010). RAMOS, Carlos Henrique. op. cit. p. 87. PIOVESAN, Flávia. Direitos Humanos e Justiça Internacional. p. 80.

Art. 111, da Constituição Italiana: "La giurisdizione si attua mediante il giusto processo regolato dalla legge".

"Essa situação causou grave transtorno político à Itália como membro da Comunidade Européia, além de natural abalo em sua soberania, principalmente em razão da forte pressão exercida pelos demais países, uma vez que tantos foram os processos de cidadãos italianos perante a Corte Européia que se causou uma morosidade da própria Corte, a qual se viu às voltas com uma carga excessiva de processos em razão da exagerada duração do processo italiano, que não conseguia mais julgar seus próprios casos em tempo adequado. Diante desse quadro, a Itália viu-se obrigada $\mathrm{a}$, inicialmente, introduzir o justo processo em sua Constituição e, às pressas, aprovar uma lei que prevê a possibilidade de os cidadãos italianos requererem indenização perante as próprias Cortes italianas, porquanto a Convenção Européia somente admite recursos à Corte 
Idem, Ibidem.

Idem, p. 583.

Idem, Ibidem.

RAMOS, Carlos Henrique. op. cit. p. 101.

Em 1988 a Assembléia Geral da OEA adotou um protocolo adicional à Convenção (Protocolo de San Salvador), concernente a direitos sociais, econômicos e culturais, o qual entrou em vigor em novembro de 1999.

PIOVESAN, Flávia. Direitos Humanos e Justiça Internacional. p. 87-88.

Idem, p. 85

ARRUDA, Samuel Miranda. op. cit. p. 162

BUERGENTHAL, Thomas. Apud. PIOVESAN, Flávia. Direitos Humanos e Justiça Internacional. p. 98.

A Comissão é composta por sete membros, de alta autoridade moral e de reconhecido saber em matéria de direitos humanos, os quais são eleitos pela Assembléia Geral da Organização, a partir de uma lista proposta pelos governos dos Estados, em que poderão indicar nomes de nacionais ou de outro Estado-membro da OEA. Os membros da Comissão têm um mandato de 4 anos, podendo ser reeleitos.

Art. 41 - A Comissão tem a função principal de promover a observância e a defesa dos direitos humanos e, no exercício de seu mandato, tem as seguintes funções e atribuições: a) estimular a consciência dos direitos humanos nos povos da América; b) formular recomendações aos governos dos estados-membros, quando considerar conveniente, no sentido de que adotem medidas progressivas em prol dos direitos humanos no âmbito de suas leis internas e seus preceitos constitucionais, bem como disposições apropriadas para promover o devido respeito a esses direitos;

c) preparar estudos ou relatórios que considerar convenientes para o desempenho de suas funções;

d) solicitar aos governos dos estados-membros que the proporcionem informações sobre as medidas que adotarem em matéria de direitos humanos; e) atender às consultas que, por meio da Secretaria-Geral da Organização dos Estados Americanos, Ihe formularem os estados-membros sobre questões relacionadas com os direitos humanos e, dentro de suas possibilidades, prestarIhes o assessoramento que Ihes solicitarem; f) atuar com respeito às petições e outras comunicações, no exercício de sua autoridade, de conformidade com o disposto nos arts. 44 a 51 desta Convenção;e g) apresentar um relatório anual à Assembléia Geral da Organização dos Estados Americanos.

VIANA, Adriana Grandinetti. op. cit. p. 170.

FRIEDRICH, Tatyana Scheila. Sistema Interamericano de Proteção de Direitos Humanos: A Comissão e a Corte Interamericana de Direitos Humanos. In: Revista da Faculdade de Direito da Universidade Federal do Paraná. Volume 33, 2000, p. 264.

Se as partes chegarem a uma solução amistosa, a Comissão redigirá um relatório que será encaminhado ao peticionário e aos Estados-partes e, posteriormente transmitido, para sua publicação, ao Secretário-Geral da Organização dos Estados Americanos. O relatório conterá uma breve exposição dos fatos e da solução alcançada.

FRIEDRICH, Tatyana Scheila. op cit, p. 264.

PIOVESAN, Flávia. Direitos Humanos e Justiça Internacional. p. 96.

"No plano consultivo, qualquer membro da OEA - parte ou não da Convenção - pode solicitar o parecer da Corte relativamente à interpretação da Convenção ou de qualquer outro tratado relativo à proteção dos direitos humanos nos Estados americanos. A Corte ainda pode opinar sobre a compatibilidade de preceitos da legislação doméstica em face dos instrumentos internacionais, efetuando, assim, o 'controle da convencionalidade das leis' [...]". (PIOVESAN, Flávia. Direitos Humanos e Justiça Internacional. p. 100).

Idem, 100-101.

O Estado Brasileiro reconheceu a competência jurisdicional da Corte Interamericana em 1998, pelo Decreto Legislativo 89.

TRINDADE, Antônio Augusto Cançado. Apud. PIOVESAN, Flávia. Direitos Humanos e Justiça Internacional. p. 103.

GODINHO, Fabiana de Oliveira. op. cit. p. 116

Art. 8․ ' 1 '. Convenção Americana: Toda pessoa terá o direito de ser ouvida, com as devidas garantias e dentro de um prazo razoável, por um juiz ou Tribunal competente, independente e imparcial, estabelecido anteriormente por lei, na apuração de qualquer acusação penal formulada 
contra ela, ou na determinação de seus direitos e obrigações de caráter civil, trabalhista, fiscal ou de qualquer outra natureza.

99 Art. $7^{\circ}, 5^{\prime}$ '. Convenção Americana - Toda pessoa presa, detida ou retida deve ser conduzida, sem demora, à presença de um juiz ou outra autoridade permitida por lei a exercer funções judiciais e tem o direito de ser julgada em prazo razoável ou de ser posta em liberdade, sem prejuízo de que prossiga o processo. Sua liberdade pode ser condicionada a garantias que assegurem o seu comparecimento em juízo.

100 TRINDADE, Antônio Augusto Cançado. Apud. VIANA, Adriana Grandinetti. op. cit. p. 176.

101 "A Corte estabeleceu o critério de cinco anos transcorridos desde o momento do auto de abertura do processo dentro dos limites da razoabilidade" (VIANA, Adriana Grandinetti. op. cit. p. 180).

102 Decisão na íntegra disponível no site: http://www.cidh.oas.org/annualrep/2000port/12051.htm. Acesso em: 06/02/2010.

103 Decisão na íntegra disponível no site: http://www.direitoshumanos.usp.br/index.php/CasosContenciosos-Importantes-julgados-pela-Corte/caso-ximenes-lopes-versus-brasil.html. Acesso em: 06/02/2010.

104 PIOVESAN, Flávia. Direitos Humanos e Justiça Internacional. p. 116.

105 PIOVESAN, Flávia. Direitos Humanos e o Direito Constitucional Internacional. p. 307.

106 Idem, p. 354.

107 Idem, p. 363.

108 PIOVESAN, Flávia. Temas de Direitos Humanos. p. 72.

\section{REFERÊNCIAS}

ARRUDA, Samuel Miranda. O Direito Fundamental à Razoável Duração do Processo. Brasília: Editora Brasília Jurídica, 2006.

CHOUKR, Fauzi Hassan. A Convenção Americana dos Direitos Humanos e o Direito Interno Brasileiro: bases para a sua compreensão. São Paulo: Editora Edipro, 2001.

COMPARATO, Fábio Konder. A Afirmação Histórica dos Direitos Humanos. 2. ed. São Paulo: Editora Saraiva, 2001.

DERGINT, Augusto do Amaral. Responsabilidade do Estado por Atos Judiciais. São Paulo: Editora Revista dos Tribunais, 1994.

DI PIETRO, Maria Sylvia Zanella. Direito Administrativo. 19. ed. São Paulo: Editora Atlas, 2006.

FARIA, J. E. O desafio do judiciário. Revista USP, Dossiê Judiciário, 1994.

FRIEDRICH, Tatyana Scheila. Sistema Interamericano de Proteção de Direitos Humanos: A Comissão e a Corte Interamericana de Direitos Humanos. In: Revista da Faculdade de Direito da Universidade Federal do Paraná. Volume 33, 2000.

GODINHO, Fabiana de Oliveira. A Proteção Internacional dos Direitos Humanos. Belo Horizonte: Editora Del Rey, 2006.

HOFFMAN, Paulo. O direito à razoável duração do processo e a experiência italiana. In: WAMBIER, Luiz Rodrigues. Reforma do Judiciário: Primeiras Reflexões sobre a Emenda Constitucional no 45/2004. São Paulo: Ed. Revista dos Tribunais, 2005. 
JUSTEN FILHO, Marçal. Empresa, Ordem Econômica e Constituição. Revista de Direito Administrativo, no 212. Rio de Janeiro, abril-junho de1998.

KOEHLER, Frederico Augusto Leopoldino. A razoável duração do processo. Salvador: Editora Podium, 2009.

MELLO, Celso Antônio Bandeira de. Curso de Direito Administrativo. 10. ed.. São Paulo: Editora Malheiros, 1998.

MUZZUOLI, Valério de Oliveira. Direitos Humanos, Constituição e os Tratados Internacionais. São Paulo: Editora Juarez de Oliveira, 2002.

PIOVESAN, Flávia. Direitos Humanos e o Direito Constitucional Internacional. 11. ed. São Paulo: Editora Saraiva, 2009.

. Direitos Humanos e Justiça Internacional. São Paulo: Editora Saraiva, 2007. . Temas de Direitos Humanos. São Paulo: Max Limonad, 2003.

RAMOS, Carlos Henrique. Processo Civil e o Princípio da Duração Razoável do Processo. Curitiba: Editora Juruá, 2008.

SILVA. Juracy C. Silva. A responsabilidade do Estado por atos judiciários e legislativos. São Paulo: Editora Saraiva, 1985.

TRINDADE, Antônio Augusto Cançado. A Proteção Internacional dos Direitos Humanos. São Paulo: Editora Saraiva, 1991.

VIANA, Adriana Grandinetti, A Razoável Duração do Processo como Mecanismo de Desenvolvimento Social. Dissertação de Mestrado defendida em 2007 na Pontifícia Universidade Católica do Paraná.

Recebido para publicação: 16/11/2010

Aceito para publicação: 23/12/2010 